\title{
Optimization of serum-free fermentation processes for antibody production
}

\author{
H. Büntemeyer, D. Lütkemeyer and J. Lehmann \\ Institute for Cell Culture Technique, University of Bielefeld, P.O. Box 86 40, 4800 Bielefeld 1, Germany
}

Key words: serum-free medium, antibody production, hybridoma, amino acid analysis, substrate utilization

\begin{abstract}
Serum free fermentation procedures of cell cultures have got a wide application in production of biochemicals. But, cells cultured in serum free media in general are more sensitive to changes in culture condition, especially to nutrient limitation. There are no substances from serum which can support the cells when conditions are changing. In this study special attention is directed to amino acid utilization of mouse hybridoma in batch, chemostat and perfusion fermentations. Detailed data are presented which show the considerable difference of amino acid consumption rates in different fermentation modes. Already, in batch mode there are differences of the two investigated mouse hybridoma cell lines, although they are derived from the same myeloma line. In chemostat running at a dilution rate representing maximal growth rate most of the consumption rates are significant higher than in batch. On the other hand, in perfusion mode the rates are lower than in batch. This indicates clearly the different conditions of the fermentation modes. Therefore, it is necessary to develop serum free processes under the desired production conditions. An accurate anaylsis of the process is strongly recommended.
\end{abstract}

\section{Introduction}

Mammalian cell culture becomes more and more important for the production of special biopharmaceuticals and biodiagnostics not only in research but also in clinical diagnostic and therapy. The products which are produced for direct application to man have to be of extremely high purity and constant quality. To guarantee this standard a well defined production method has to be established and also all raw materials which are used in the process have to be of constant quality.

In many processes several serum compositions (fetal calf serum, newborn calf serum, horse serum, human serum) are used. Serum contains many proteins, peptides, growth factors, hormones and other components which may be of importance for the cells to be cultivated. But, the concentrations of these components differ from charge to charge. Therefore, each charge can have a different ability for promoting cell growth and product formation. The use of a totally defined serum free medium can overcome this problem if it is possible to adapt the cells to this conditions without loss of productivity (Takazawa et al., 1988).

The importance of serum for basic nutrition (e.g., glucose, amino acids) is low if it is used in contents of $5-10 \%$ of the complete medium. Serum contains almost all amino acids (Table 1) 
Table 1. Amino acid content of fetal calf serum (Boehringer Mannheim, Germany), analysed with the method described in this study

\begin{tabular}{lc}
\hline Amino acid & $\begin{array}{c}\text { Concentration } \\
\mu \mathrm{mol} \mathrm{L}^{-1}\end{array}$ \\
\hline ALA & 1198 \\
ASP & 77 \\
GLN & 747 \\
GLU & 371 \\
GLY & 770 \\
HIS & 87 \\
ILE & 146 \\
LEU & 277 \\
LYS & 161 \\
MET & 31 \\
ORN & 210 \\
PHE & 129 \\
SER & 310 \\
THR & 274 \\
TRP & 69 \\
TYR & 101 \\
VAL & 333 \\
\hline
\end{tabular}

but the concentrations are not as high as it can work as pool for amino acids. Nevertheless, there is a pool of useful substances in serum which can support the cells under culture conditions. These substances are not existing in serum free medium. Therefore, serum free cultures are more sensible to changes in culture conditions. Especially nutrient limitation can cause changes in cell behaviour in respect to process stability. Cell specific parameters (growth rate, nutrient consumption rates) can help to characterize the cell status. Unfortunately, these parameters are not constant for one cell line. They are affected by the culture conditions (e.g., $\mathrm{pH}, \mathrm{T}, \mathrm{pO}_{2}$, agitation) and by the fermentation method (e.g., batch, fed batch, chemostat, perfusion, dense cell system). For the development and optimization of a production process it is necessary to analyse as much parameters as possible under the desired production conditions.

In this study the changes of nutrient requirements, especially amino acids, of two mouse hybridoma cell lines in different fermentation modes are shown and discussed.

\section{Bioreactor systems}

For the production of monoclonal antibodies a wide variety of technical systems are available. The most used systems are stirred reactors in different modes: batch, chemostat or perfusion. As an advantage of homogeneous suspension cultures the cells and their behaviour are easy to observe. At every time it is possible to get representative samples to analyse nutrients and cell numbers.

In chemostat culture the cell density is much lower than in perfusion culture but in perfusion culture sufficient feeding of all nutrients generally is more difficult, because of the high cell density and the low concentration of some amino acids in commercially available culture media. Therefore, the concentrations of the nutrients have to be monitored and analysed carefully.

Two examples for the cultivation in these modes are discussed below.

\section{Chemostat reactor}

The chemostat reactor used in this study was a Biostat BF with $2 \mathrm{~L}$ stirred culture vessel (B. Braun, Melsungen, Germany) equipped with a membrane stirrer with $2 \mathrm{~m}$ polypropylene hollow fibre membrane tubing per litre for bubble free aeration (Lehmann et al., 1988). The medium exchange was carried out using two peristaltic pumps (Watson-Marlow 501-UR). Temperature was set to $37^{\circ} \mathrm{C}$, pH to 7.2 and $\mathrm{pO}_{2}$ to $40 \%$ air saturation.

\section{Perfusion reactor}

This $2 \mathrm{~L}$ reactor (the same as above) was equipped with a membrane basket with $2 \mathrm{~m}$ silicone tubing per litre for aeration and $2 \mathrm{~m}$ hydrophilized polypropylene hollow fibre membrane tubing per litre for medium exchange. The microfiltration membrane $(0.3 \mu \mathrm{m})$ was connected at the input side via a peristaltic pump (Watson-Marlow 501UR) with the medium reservoir and at the output 
side via another pump with the harvest tank. These two perfusion pumps run alternatively controlled by a system creating a process cycle of harvesting and feeding depending on reactor volume and pump speed. Running this cycle perfusion was carried out (Büntemeyer 1988). Additionally, a third pump was connected to the reactor directly for cell harvest. It was necessary to remove cells from the reactor to reach steady state conditions (Büntemeyer et al. 1987). Physiological setpoints $\left(\mathrm{pH}, \mathrm{pO}_{2}, \mathrm{~T}\right)$ were set to the same values as in the chemostat experiments.

\section{Materials and methods}

\section{Cells}

The cell lines used in this study were mouse hybridoma (mouse myeloma P3X63-Ag8.653 subclone/BALB/c) secreting monoclonal antibodies (Köhler and Milstein, 1975). The cell line GL3 used in the perfusion reactor secreted a monoclonal antibody against gelsolin. For the chemostat experiments the mouse hybridoma VIN2 producing a monoclonal antibody against vinculin was used. These two antigens are proteins of the cytoskeleton of mammalian cells (Jockusch et al. 1986). Both cell lines were kindly supplied by Prof. Dr. B.M. Jokusch, Department of Biology, University of Bielefeld.

Cell numbers were determined microscopically by trypan blue exclusion.

\section{Medium}

The serum free medium was a 1:1 mixture of IMDM and Ham's F12 supplemented with $2 \mathrm{mM}$ L-glutamine, $2 \mathrm{mM}$ pyruvate, $20 \mu \mathrm{M}$ ethanolamine, $1 \mathrm{~g} / \mathrm{L}$ bovine serum albumin complexed with $4 \mathrm{mg}$ oleic acid, $10 \mathrm{mg} / \mathrm{L}$ human transferrin (Fe saturated), $10 \mathrm{mg} / \mathrm{L}$ bovine insulin (Jäger et al., 1988). The medium and the supplements were sterilized by membrane filtration 0.2 $\mu \mathrm{m})$.

\section{Amino acid analysis}

The free amino acids in the samples of the fermentations were analysed using an automated reversed phase high performance liquid chromatographic system (RP-HPLC) with precolumn derivatization using the OPA method.

The HPLC system was a Kontron D 450 system consisting of two HPLC pumps type 420, an autosampler type 460, a fluorometer SFM 25 and a data system MT 450 .

\section{Sample preparation}

All samples from fermenter or culture flask origin were centrifuged for $5 \mathrm{~min}(1500 \times \mathrm{g})$ to remove all cells and debris. For the removal of the proteins $50 \mu \mathrm{L}$ of the supernatant were mixed with the same volume of $3 \%$ perchloric acid in water containing also $300 \mu \mathrm{M}$ B-alanine as internal standard. This solution was centrifuged $3 \mathrm{~min}$ $(14500 \times \mathrm{g}) .50 \mu \mathrm{L}$ of the supernatant were mixed with $100 \mu \mathrm{L}$ of sodium borate buffer $(0.4 \mathrm{M}, \mathrm{pH}$ 9.5) to guarantee a $\mathrm{pH}$ above $\mathrm{pH} 8.10 \mu \mathrm{L}$ of this solution was filled into a special autosampler vial for automatic processing.

\section{Derivatization procedure (OPA method)}

The derivatization solution was prepared by dissolving $100 \mathrm{mg}$ o-phthaldialdehyde (OPA) and $100 \mu \mathrm{L} 2$-mercaptoethanol in $1.5 \mathrm{~mL}$ methanol and filled up with sodium borate buffer $(0.4 \mathrm{M}$ $\mathrm{pH} 9.5$ ) to a final volume of $7 \mathrm{~mL}$. This solution is stable for 2 days at room temperature. The $\mathrm{pH}$ of 9.5 is necessary for the derivatization of the amino acids with o-phthaldialdehyde to guarantee a not protonized primary amino group.

The derivatization of the free amino acids in the prepared sample solution was carried out automatically by the autosampler system.

$80 \mu \mathrm{L}$ of the OPA solution was filled into the sample vial and mixed for 30 secs. The total reaction time was set to $1.5 \mathrm{~min}$. After that time $15 \mu \mathrm{L}$ were injected onto the column.

\section{HPLC conditions}

For the separation and quantification of all amino acids a binary multi step gradient system was 
necessary (Bober 1986; Büntemeyer 1988; Wagner et al. 1988).

\section{Buffer A:}

Buffer B:

$85 \%$ sodium acetate $\mathrm{pH} 6.5$

$14 \%$ methanol

$20 \%$ sodium acetate $\mathrm{pH} 6.0$

$80 \%$ methanol

$1 \%$ tetrahydrofuran

Each complete analysis including derivatization, column washing, equilibration and calculation takes a time of $60 \mathrm{~min}$. Fig. 1 represents a standard run.

\section{HPLC columns}

The HPLC column was a Beckman Ultraphere ODS $5 \mu, 250 \times 4.6 \mathrm{~mm}$, (Beckman, München, Germany) reversed phase column set to a temperature of $22^{\circ} \mathrm{C}$ using a water jacket and a thermostat. To prevent a fast fouling of the column a guard column filled with RP material Shandon ODS Hypersil $10 \mu, 10 \times 4.6 \mathrm{~mm}$, (Techlab, Erkerode, Germany) was placed in front of the main column.

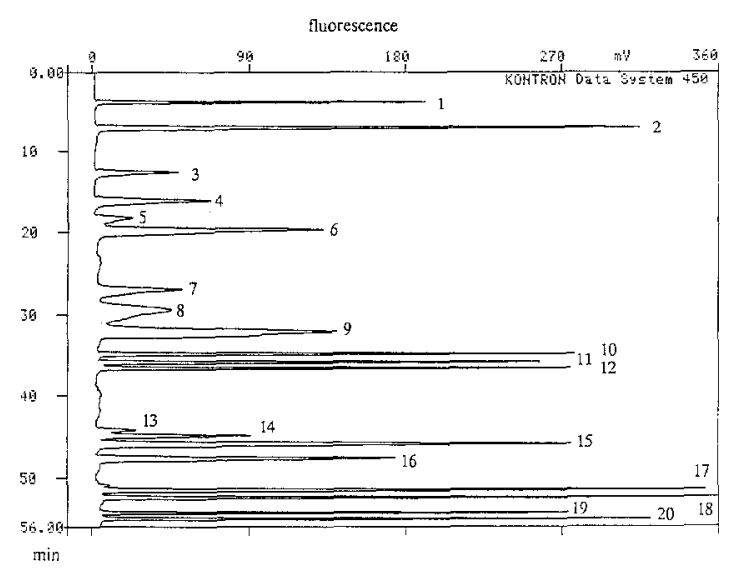

Fig. 1. HPLC calibration run with all detectable amino acids in concentrations representing a 1:1 mixture of cell culture media IMDM and F12 except LYS (two fold concentration) and ORN (occurs not in IMDM/F12, concentration like LYS).

$1=\mathrm{ASP}, 2=\mathrm{GLU}, 3=\mathrm{ASN}, 4=\mathrm{SER}, 5=\mathrm{HIS}, 6=\mathrm{GLN}, 7=$ GLY, $8=$ THR, $9=$ ARG, $10=$ B-ALA (internal standard), $11=$ ALA, $12=$ TYR, $13=$ TRP, $14=$ MET, $15=$ VAL, $16=$ PHE, $17=$ ILE, $18=$ LEU, $19=$ ORN, $20=$ LYS.

\section{Standardization}

Stock solutions of all primary amino acids which occur in cell culture media were prepared by dissolving the substances (analytical grade) in purified water (Milli-Q, Millipore). These stock solutions were aliquoted and stored at $-20^{\circ} \mathrm{C}$. From those stock solutions a ready-to-inject solution was prepared just before analysis. This solution contained the amino acids in such concentrations as in the used medium composition.

\section{Calculation and quantification}

Calibration factors were calculated from standard runs. Sample quantification was carried out using the internal standard method. B-alanine was used as internal standard because it does not appear in animal cell metabolism.

The reproducibility of the calculated amino acid concentrations of the supernatant using this internal standard method was better than $5 \%$ for each amino acid except of lysine, because of the low fluorescence response of its OPA derivate.

\section{Glucose and lactic acid analysis}

Glucose and lactic acid concentrations were analysed using an automatic analyser system based on enzymatic and electrochemical reactions (YSI 2000, Yellow Springs Instruments, OH, USA).

\section{Antibody concentration}

Antibody concentrations in the supernatant were analysed by a kinetic sandwich ELISA method. The enzyme linked to the antibody (goat anti mouse antibody) was peroxidase converting $O$ phenylenediamine as substrate. For the kinetic analysis in each microplate well (standards and samples) an experimental point was taken every 3 minutes to control the complete enzyme reaction. In the linear part of this conversion curve (extinction versus time) the slope was calculated and correlated to the content of the standard solution. From this calibration function sample concentrations of several dilution steps were calculated. 


\section{Chemicals}

Water for fermentation and HPLC was prepared by a Milli-Q system (Millipore, Bedford, MA, USA). All chemicals were of analytical grade. Organic solvents (methanol, tetrahydrofuran) were purchased from Baker (Philipsburg, NJ, USA), cell culture media from Gibco (Paisley, UK). All other chemicals were purchased from Sigma (St. Louis, MO, USA) except bovine serum albumin, glutamine (Serva, Heidelberg, Germany), o-phthalaldehyde, $o$-phenylenediamine (Aldrich, Steinheim, Germany) and antibodies for ELISA (Medac, Hamburg, Germany).

\section{Results}

For the determination of cell specific parameters the two hybridoma cell lines GL3 and VIN2 were cultivated in different modes. Hybridoma VIN2 was cultivated in batch and chemostat mode, hybridoma GL3 in batch and perfusion mode with cell harvest. For the comparison of the two cell lines and cultivation methods specific parameters for cell growth, substrate utilization and product formation were calculated following the equations listed below (Pirt, 1985).

Equations for the calculation of cell specific parameters

I. Batch:

Cell growth:

$$
\mu=\frac{1}{x} \cdot \frac{\mathrm{d} x}{\mathrm{~d} t} \quad\left[\mathrm{~d}^{-1}\right]
$$

Specific substrate utilization:

$$
q_{s}=\frac{1}{x} \cdot \frac{\mathrm{d} c_{s}}{\mathrm{~d} t} \quad[\text { mole/cells } \cdot \mathrm{d}]
$$

Growth yield:

$$
\left.Y_{x / s}=\frac{\mu}{q_{s}} \quad \text { [cells } / \text { mole }\right]
$$

Specific production:

$$
q_{p}=\frac{1}{x} \cdot \frac{\mathrm{d} p}{\mathrm{~d} t} \quad[\mathrm{~g} / \text { cells } \cdot \mathrm{d}]
$$

II. Chemostat:

Cell growth:

$$
\frac{\mathrm{d} x}{\mathrm{~d} t}=\mu x-D_{H} x
$$

Specific substrate utilization:

$$
\frac{\mathrm{d} c_{s}}{\mathrm{~d} t}=D\left(c_{0}-c_{s}\right)-q_{s} x
$$

Specific production:

$$
\frac{\mathrm{d} p}{\mathrm{~d} t}=q_{p}-D p
$$

III. Perfusion:

Cell growth:

$$
\frac{\mathrm{d} x}{\mathrm{~d} t}=\mu x
$$

Specific substrate utilization:

$$
\frac{\mathrm{d} c_{s}}{\mathrm{~d} t}=D_{P}\left(c_{0}-c_{s}\right)-q_{s} x
$$

Specific production:

$$
\frac{\mathrm{d} p}{\mathrm{~d} t}=q_{p}-D p
$$

IV. Perfusion with cell harvest (mixed perfusion and chemostat)

Cell growth:

$$
\frac{\mathrm{d} x}{\mathrm{~d} t}=\mu x-D_{H} x
$$


Specific substrate utilization:

$$
\frac{\mathrm{d} c_{s}}{\mathrm{~d} t}=D\left(c_{0}-c_{s}\right)-q_{s} x
$$

Specific production:

$$
\frac{\mathrm{d} p}{\mathrm{~d} t}=q_{p}-D p
$$

\section{Symbols}

$\begin{array}{lll}x & \text { viable cell density } & {[\mathrm{cells} / \mathrm{mL}]} \\ t & \text { time } & {[\mathrm{d}]} \\ \mu & \text { specific growth rate } & {\left[\mathrm{d}^{-1}\right]} \\ c_{s} & \text { substrate concentration } & {[\mathrm{mole} / \mathrm{L}]} \\ c_{0} & \text { substrate medium concentration } & {[\mathrm{mole} / \mathrm{L}]} \\ q_{s} & \text { specific substrate utilization rate } & {[\mathrm{mole} / \mathrm{cells} \cdot \mathrm{d}]} \\ p & \text { product concentration } & {[\mathrm{g} / \mathrm{L}]} \\ q_{p} & \text { specific production rate } & {[\mathrm{g} / \mathrm{cells} \cdot \mathrm{d}]} \\ Y & \text { growth yield } & {[\mathrm{cells} / \mathrm{mole}]} \\ D & \text { total dilution rate } D=D_{H}+D_{P} & {\left[\mathrm{~d}^{-1}\right]} \\ D_{H} & \text { cell harvest rate } & {\left[\mathrm{d}^{-1}\right]} \\ D_{P} & \text { perfusion rate } & {\left[\mathrm{d}^{-1}\right]}\end{array}$

\section{Calculation procedure}

For the calculation of all amino acid consumption rates in the batch phase it was necessary to have a reference (Table 2). The reference time for batch mode was set to the latest time when $\mu=\mu_{\max }$ before $\mu$ decreases. For this purpose a function was correlated mathematically to the cell proliferation curve. From the first order derivative $(\mathrm{d} x / \mathrm{d} t)$ of this function a $\mu(t)$ curve was calculated using equation (1). An example for the batch phase of GL3 is displayed in Fig. 2.

The specific rates of all nutrients were calculated in a similar way using equation (2). From Fig. 3 it can be seen that $\mathrm{q}_{\mathrm{s}}$ is not constant. Table 3

Table 2. Cell specific parameters $\mu_{\max }$ and $q_{\mathrm{p}}$ for both hybridoma cell lines (calculated from each batch phase)

\begin{tabular}{lll}
\hline Cell line & VIN2 & GL3 \\
\hline$\mu_{\max }\left[\mathrm{d}^{-1}\right]$ & 1 & 0.63 \\
$\mathrm{q}_{\mathrm{p}}\left[\mu \mathrm{g} \cdot 10^{-6}\right.$ cells $\left.\cdot \mathrm{d}^{-1}\right]$ & 4 & 5 \\
\hline
\end{tabular}

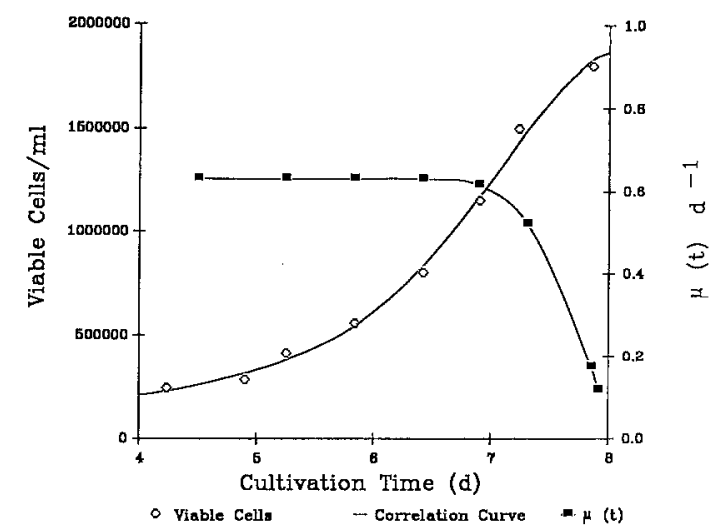

Fig. 2. Estimation of the time course of function $\mu(t)$. $\mu$ was calculated in the batch phase of the fermentation of hybridoma GL3.

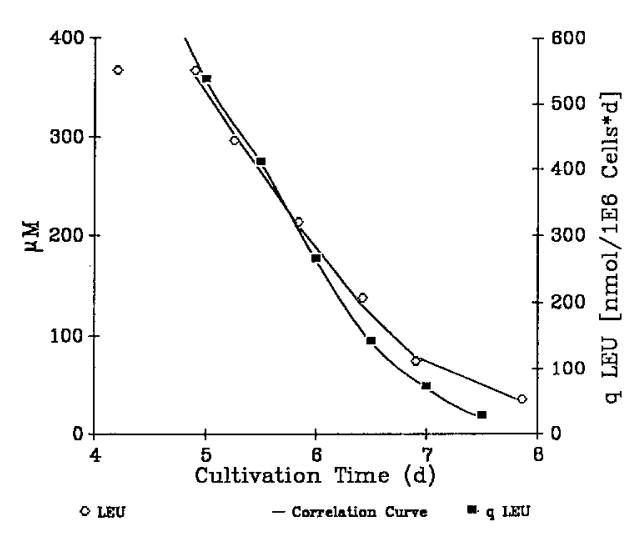

Fig. 3. Specific consumption rate of leucine as a function of time, calculated in the batch phase of fermentation of hybridoma GL3.

summarizes all values calculated for both cell lines. The specific rates listed in the batch columns are related to the reference time of the indicated batch fermentation.

All specific parameters in chemostat or perfusion mode were calculated with the corresponding equations $(5-13)$ under steady state conditions when

$$
\frac{\mathrm{d} x}{\mathrm{~d} t}=0, \frac{\mathrm{d} c_{s}}{\mathrm{~d} t}=0, \frac{\mathrm{d} p}{\mathrm{~d} t}=0 .
$$

The results are listed also in Table 3. 
Table 3. Specific consumption rates $\mathbf{q}_{\mathbf{s}}$ of all amino acids, glucose and lactic acid for both estimated hybridoma cell lines (VIN2, GL3). All values are given in nmol. $10^{-6} \mathrm{cells} \cdot \mathrm{d}^{-1}$

\begin{tabular}{|c|c|c|c|c|}
\hline \multirow{2}{*}{$\begin{array}{l}\text { Cell line } \\
\text { substrate }\end{array}$} & \multicolumn{2}{|l|}{ VIN2 } & \multicolumn{2}{|l|}{ GL3 } \\
\hline & Batch & Chemostat & Batch & Perfusion \\
\hline ASP & 54.8 & 103.6 & 31.3 & 0.9 \\
\hline GLU & 29.1 & 190.0 & 55.1 & -7.7 \\
\hline ASN & 52.1 & 48.2 & 48.0 & 26.1 \\
\hline SER & 231.8 & 109.5 & 57.6 & -86.9 \\
\hline GLN & 3595.3 & 2075.9 & 1323.1 & 1162.4 \\
\hline GLY & 72.1 & 303.4 & 36.8 & 40.0 \\
\hline THR & 128.7 & 197.5 & 101.9 & 116.3 \\
\hline ARG & 199.3 & 203.9 & 144.0 & 64.7 \\
\hline ALA & -400.8 & -878.6 & -2121.0 & -562.8 \\
\hline TYR & 95.7 & 189.1 & 65.4 & 41.1 \\
\hline TRP & 17.0 & 11.8 & 13.9 & 10.9 \\
\hline MET & 55.1 & 80.7 & 38.7 & 42.7 \\
\hline VAL & 143.7 & 279.4 & 128.7 & 115.4 \\
\hline ILE & 75.7 & 245.1 & 129.7 & 129.3 \\
\hline LEU & 41.1 & 312.5 & 167.2 & 135.7 \\
\hline LYS & 54.5 & 292.1 & 30.3 & 7.3 \\
\hline Glucose & 8035.91 & 8163.0 & 1690.6 & 1631.4 \\
\hline Lactic acid & -8558.6 & -11009.0 & -675.5 & -1052.9 \\
\hline
\end{tabular}

\section{Chemostat fermentation}

The cells, secreting a monoclonal antibody against vinculin, were cultivated over a period of 20 days. During the first three days the cells grew from $2 \times 10^{5}$ cells $/ \mathrm{mL}$ up to $3 \times 10^{6}$ cells $/ \mathrm{mL}$ in

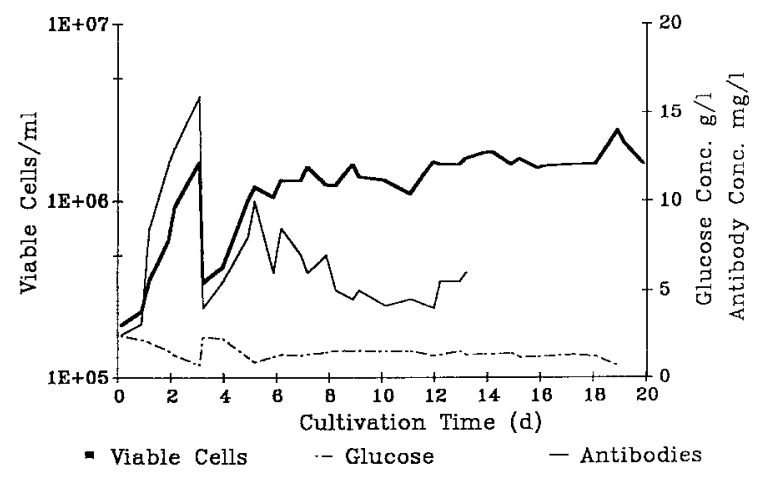

Fig. 4. Time course of the fermentation of hybridoma VIN2. Shown are the courses of viable cell density, glucose and antibody concentrations. First batch phase till day 3 , second batch phase from day 3 to day 5 , chemostat phase from day 5 to day 20 . batch mode. Then the cells died, because of nutrient limitation. After diluting the fermentation suspension with fresh medium the cells started to grow again (Fig. 4). Beginning at day 5, the chemostat was started with a dilution rate of $\mathrm{D}=$ $1 \mathrm{~d}^{-1}$. During the following 15 days the cell density was kept at $1.3-1.8 \times 10^{6}$ cells $/ \mathrm{mL}$. At this time almost all amino acid concentrations were constant at a low level except alanine which was produced by the cells. From the amino acid content of the medium and the calculated specific consumption rates it was obvious that methionine would be the first amino acid running into limitation. The methionine concentration did not fall to zero but was constant at a level of $25 \mu \mathrm{mol} / \mathrm{L}$ (Fig. 5). The steady state viable cell density was $1.35 \times 10^{6}$ cells $/ \mathrm{mL}$. Beginning at day 9 of the fermentation the feeding medium was supplemented with methionine and tryptophan in the way that the new concentrations were twice the time of the original medium concentration. This resulted in a small increase of steady state viable cell density to a level of $1.65 \times 10^{6}$ cells $/ \mathrm{mL}$ 


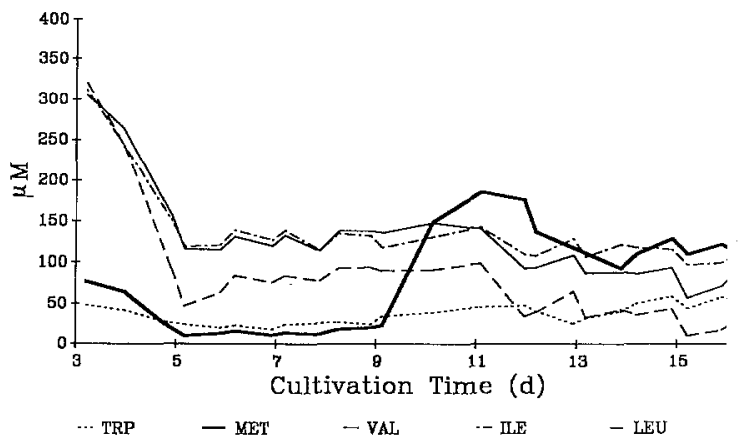

Fig. 5. Amino acid concentration during the chemostat fermentation of hybridoma VIN2. Shown are the concentrations of the amino acids TRP, MET, VAL, ILE, LEU beginning at day 3 with a 2 days batch phase, continuing with the chemostat phase. From the day 9 the methionine and tryptophan concentrations were doubled in respect to the basal medium.

indicating another amino acid limitation (ILE). There was no effect on viable cell density by increasing the isoleucine concentration in the feeding medium, because most of the amino acids had a growth yield $Y_{X / S}$ of about $1.7 \times 10^{6}$

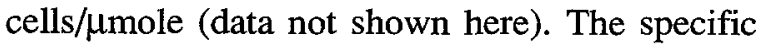
antibody production during the batch phase was quite the same as during the chemostat phase and was amounted to $4 \mu \mathrm{g} \times 10^{-6}$ cells $\times \mathrm{d}^{-1}$.

\section{Perfusion fermentation}

The fermentation of the hybridoma cell line GL3, secreting a monoclonal antibody against gelsolin,

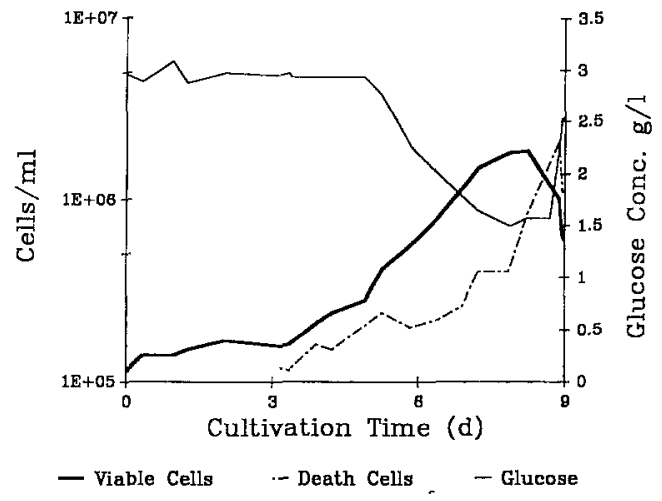

Fig. 6. Time course of the first part of the fermentation of hybridoma GL3. Shown are viable and death cell concentrations and glucose concentration during the batch phase of the fermentation.

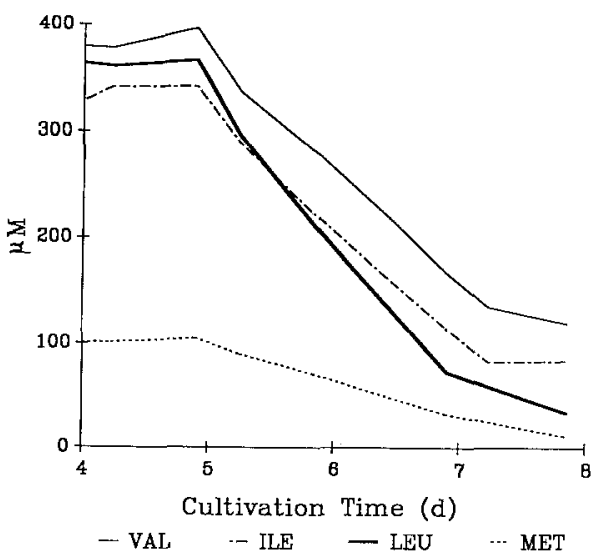

Fig. 7. Time course of amino acid consumption of VAL, ILE, LEU, MET during batch phase of the fermentation of hybridoma GL3.

was subdivided into two parts: first part batch; second part perfusion with cell harvest.

In the first part (Figs. 6 and 7) when the rates of consumption of all nutrients were calculated (Table 3), the cells grew up to a density of $1.8 \times$ $10^{6}$ cells $/ \mathrm{mL}$. Then the cells died, because of the limitation of amino acids (glutamine, methionine); glucose concentration was not important in this period. Then half of the volume of the fermenter was drained off and filled up again with fresh medium to start part two of the fermentation. The cells grew again and in this second part (Fig. 8) of the fermentation the fermenter was fed with fresh medium as described above

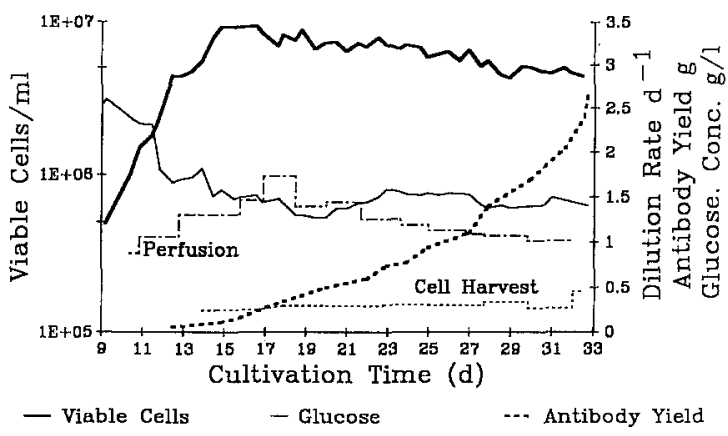

Fig. 8. Time course of the perfusion phase of the fermentation of hybridoma GL3. Shown are viable cell density, glucose concentration and antibody yield during this phase. Perfusion rate $D_{P}$ and cell harvest rate $D_{H}$ also are displayed for continuous phase. 
Table 4. Amino acid concentrations of basal (1:1 mixture HAM's F12 and IMDM) and perfusion medium (basal medium with addition of selected amino acids)

\begin{tabular}{lcc}
\hline Amino acid & Basal medium $\mu \mathrm{mol} / \mathrm{L}$ & Perfusion medium $\mu \mathrm{mol} / \mathrm{L}$ \\
\hline ASP & 162.7 & 162.7 \\
GLU & 304.9 & 304.9 \\
ASN & 144.6 & 289.2 \\
SER & 249.7 & 249.7 \\
GLN & 2500 & 7500 \\
GLY & 499.3 & 499.3 \\
THR & 448.8 & 448.8 \\
ARG & 700 & 700 \\
ALA & 190.2 & 190.2 \\
TYR & 309 & 309 \\
TRP & 44.2 & 88.4 \\
MET & 115.5 & 346.5 \\
VAL & 450.9 & 901.8 \\
ILE & 415.2 & 830.4 \\
LEU & 450.1 & 900.2 \\
LYS & 499.5 & 499.5 \\
HIS & 150.2 & 225.3 \\
PHE & 218.7 & 437.4 \\
\hline
\end{tabular}

(perfusion procedure). The feeding rate was raised from $D_{P}=0.8 \mathrm{~d}^{-1}$ at the beginning, up to a maximum of $D_{p}=1.7 d^{-1}$; then cell harvest was started. Further changes of $D_{P}$ were necessary to stabilize the steady state. The medium used in this part was optimized by supplementation of the limiting amino acids. The concentrations of asparagine, tryptophan, valine, isoleucine, leucine and phenylalanine were double, methionine and glutamine were triple and histidine was one and a half the time in respect to the basal medium, respectively (Table 4).

With this medium it was possible to supply $1 \times$ $10^{7}$ cells $/ \mathrm{mL}$. At $1 \times 10^{7}$ cells $/ \mathrm{mL}$ cell harvest was started to reach a steady state. During the rest of the fermentation $0.5-0.7 \mathrm{~L} \times \mathrm{d}^{-1}$ fermentation suspension were removed to keep the steady state constant. For a period of 20 days this steady state was kept at a viable cell density of approx. $7 \times$ $10^{6}$ cells $/ \mathrm{mL}$. The amino acid concentrations in this period were constant, also indicating that a steady state point was really reached (Fig. 9). These steady state conditions of optimal supply led to an antibody production of $8 \mu \mathrm{g} \times 10^{-6}$ cells $\times d_{-}$. This was remarkable higher than the productivity of $5 \mu \mathrm{g} \times 10^{-6}$ cells $\times \mathrm{d}^{-1}$ observed in batch culture during exponential growth.

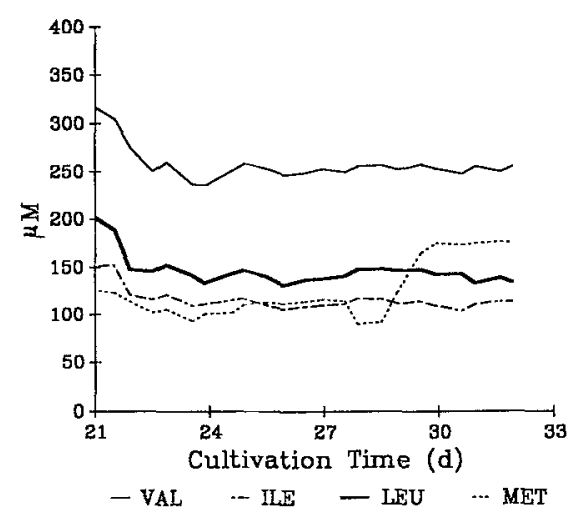

Fig. 9. Amino acid concentrations during the steady state of the perfusion phase of the fermentation of hybridoma GL3. Displayed are the four amino acids VAL, ILE, LEU and MET.

\section{Discussion}

From the data of the two fermentation it is obvious that amino acid concentrations in serum free medium are of tremendous importance for growth and production in animal cell cultures (Eagle 1959). The glucose concentration is not as interesting as some selected amino acid concentrations. For the development of a production 
system it is strongly recommended to optimize under the desired fermentation mode, because nutrient consumption can change dramatically by switching from mode to mode.

In the fermentations discussed above, glutamine and especially methionine were of high importance for both cell lines (Arwadi et al. 1984; Zielke et al. 1984). The calculation of amino acid consumption rates made it possible to compare both cell lines. Furthermore, this calculation gave the opportunity to optimize the medium for the perfusion fermentation, which was the premise for the high density cultivation of these cells.

In comparison, the consumption rates of both cell lines in batch phase are of same order except glucose and some of the amino acids. The cell line VIN2 uses much more glucose and glutamine for energy requirement leading to a higher growth rate but not to a higher production rate.

The consumption rates in chemostat phase of VIN2 are in most cases twice as high as in batch phase. The reason for this effect possibly is wash out of waste products and inhibitors and that constant conditions resulting in a chemostat growth rate of $\mu_{\max }$. These good conditions do not result in a higher productivity. The first limiting substance in chemostat culture was methionine, already expected from consumption rate and medium content.

In the perfusion experiment using cell line GL3 the situation is quite different from chemostat culture of VIN2. In most cases the consumption rates are lower than in the related batch phase. Steady state growth rate also is lower than $\mu_{\max }$, but productivity is higher. This can be caused by cell interaction, self conditioning effects and good nutrition supply (Duval et al. 1989; Geaugey et al. 1989).

A very interesting amino acid is serine. During VIN2 fermentation the consumption rate decreased switching from batch to chemostat mode. In perfusion mode of GL3 fermentation it is already produced. In contrast to these results human lymphoid cells are strongly dependent on serine, also in high cell density culture (Birch $e t$ al. 1977; Büntemeyer 1988).
Following conclusions can be taken:

- a better antibody harvest is obtained by perfusion fermentation;

- medium optimization is necessary for high density culture;

- monitoring of amino acid consumption is very helpful;

- process development for the desired production mode is recommended.

\section{Acknowledgement}

We thank Mrs. B. Bernat for excellent technical assistance.

\section{References}

Arwadi MSM and Newsholme EA (1984) Glutamine metabolism in lymphoid tissues. In: Häussinger D, Sies $H$ (eds.) Glutamine Metabolism in Mammalian Tissues (pp. 235-246) Springer.

Birch JR and Hopkins DW (1977) The serine and glycine requirements of cultured human lymphocyte lines. In: Acton RT and Lynn JD (eds.) Cell culture and its applications (pp. 503-511) Academic Press.

Bober H (1986) Über Möglichkeiten der HPLC zur Trennung und Bestimmung von Aminosäuren I. Trennung von Hydrolysatgemischen Beckman Report 1986: 3.

Büntemeyer H (1988) Entwicklung eines Perfusionssystems zur kontinuierlichen Kultivierung tierischer Zellen in Suspension. Ph.D. Thesis, University of Hannover, Germany.

Büntemeyer H, Bödeker BGD and Lehmann J (1987) Membrane-stirrer-reactor for bubble free aeration and perfusion. In: Spier RE and Griffiths JB (eds.) Modern Approaches to Animal Cell Technology (pp. 411-419) Butterworths.

Duval D, Geahel I, Dufau AF and Hache J (1989) Effect of amino acids on the growth and productivity of hybridoma cell cultures. In: Spier RE, Griffiths JB, Stephenne J and Crooy PJ (eds.) Advances in animal cell biology and technology for bioprocesses (pp. 257-259) Butterworths.

Eagle H (1959) Amino acid metabolism in mammalian cell cultures. Science 130: 432-437.

Geaugey V, Duval D, Geahel I, Marc A and Engasser JM (1989) Influence of amino acids on hybridoma cell viability and antibody secretion. Cytotechnology 2: 119-129.

Jäger V, Lehmann J and FriedI P (1988) Serum-free growth medium for the cultivation of a wide spectrum of mammalian cells in stirred bioreactors. Cytotechnology 1: 319-329.

Jockusch BM, Füchtbauer A, Wiegand C, Höner C and Höner B (1986) Probing the cytoskeleton by microinjection. In: Shay JW (ed.) Celland molecular biology of the cytoskeleton (pp. 1-40) Plenum Publishing. 
Köhler G and Milstein C (1975) Continuous cultures of fused cells secreting antibody of predefined specifity. Nature 256 : 495-497.

Lehmann J, Vorlop J and Büntemeyer H (1988) Bubble free reactors and their development for continuous culture with cell recycle. In: Spier RE and Griffiths JB (eds.) Animal Cell Biotechnology 3 (pp. 221-237) Academic Press.

Pirt SJ (1985) Principles of microbe and cell cultivation (pp. 209-222) Blackwell Scientific Publications.

Takazawa Y, Tokashiki M, Murakami H, Yamada K and Omura $\mathrm{H}$ (1988) High-density culture of mouse-human hybridoma in serum-free defined medium. Biotechnol. Bioeng. 31: 168172.
Wagner R, Ryll T, Krafft H and Lehmann J (1988) Variation of amino acid concentrations in the medium of HU B-IFN and HU IL-2 producing cell lines. Cytotechnology 1: 145-150.

Zielke HR, Sumbilla CM, Zielke CL, TiIdon JT and Ozand PT (1984) Glutamine metabolism by cultured mammalian cells. In: Häussinger and Sies $H$ (eds.) Glutamine Metabolism in Mammalian Tissues (pp. 247-254) Springer.

Address for offprints: H. Büntemeyer, Institute for Cell Culture Technique, University of Bielefeld, P.O., Box 8640,4800 Bielefeld 1, Germany 